\title{
ISOLASI DAN IDENTIFIKASI Aspergillus Spp PADA PARU-PARU AYAM KAMPUNG YANG DIJUAL DI PASAR BANYUWANGI
}

\section{Isolation and Identification of Aspergillus Spp from The Lungs of Native Chicken which Sell in Banyuwangi Market}

\author{
Ratih Novita Praja ${ }^{1 *}$, Aditya Yudhana ${ }^{2}$ \\ ${ }^{1}$ Laboratorium Bakteriologi dan Mikologi, Departemen Mikrobiologi Veteriner, \\ ${ }^{2}$ Laboratorium Parasitologi, Departemen Parasitologi Veteriner, \\ Kampus C UNAIR Jln. Mulyorejo, Surabaya, Jawa Timur, Indonesia, 60115 \\ Telp.(031) 5993016, Fax.(031) 5990315 \\ *Corresponding author: ratihvet.unair@gmail.com
}

\begin{abstract}
Abstrak
Penelitian ini bertujuan untuk mengisolasi dan mengidentifikasi Aspergillus Spp pada paru-paru ayam kampung. Sampel yang digunakan dalam penelitian ini adalah 20 paru-paru ayam kampung yang diambil secara acak dari Pasar Banyuwangi yang terletak pada wilayah tengah Kota Banyuwangi, Jawa Timur. Sampel dicuci dengan aquades steril yang berisi antibiotik selanjutnya ditanamkan pada media spesifik Sabouraud's Dextrose Agar (SDA) kemudian diinkubasikan pada suhu kamar selama 3-7 hari. Pertumbuhan morfologi Aspergillus diamati secara makroskopis. Koloni yang diduga Aspergillus Spp diperiksa secara mikroskopis. Data yang diperoleh dianalisis secara deskriptif. Hasil pemeriksaan menunjukkan bahwa Aspergillus Spp dapat diisolasi pada 9 dari 20 sampel paru-paru. Dapat disimpulkan bahwa 45\% sampel paru-paru yang diperiksa positif terinfeksi Aspergillus Spp dan 55\% bebas dari infeksi Aspergillus Spp.
\end{abstract}

Kata kunci: Aspergillus Spp, paru-paru, ayam kampung, Pasar Banyuwangi

\begin{abstract}
This research aimed to isolate and identify Aspergillus Spp from the lungs of native chicken. Samples used in this study were 20 chicken lungs taken randomly from the Banyuwangi Market which located in the middle of Banyuwangi City, East Java. The samples were washed with sterile aquadest containing antibiotics before cultured on specific media Sabouraud's Dextrose Agar (SDA), then incubated at room temperature for 3 7 days. The plate was observed from Aspergillus Spp colony macroscopically and microscopically. Data were analyzed descriptively. The result of examination showed that Aspergillus Spp can be isolated from 9 out of 20 lungs. It can be concluded that $45 \%$ of the lung samples are infected with Aspergillus Spp and 55\% are free from Aspergillus Spp infection.
\end{abstract}

Key words: Aspergillus Spp, lungs, native chicken, Banyuwangi Market

\section{PENDAHULUAN}

Indonesia sebagai negara tropis kondisinya sangat memadai untuk pertumbuhan berbagai macam jamur termasuk Aspergillus. Aspergillus merupakan spesies jamur yang tersebar secara kosmopolitan, karena spora jamur yang mudah disebarkan oleh angin, mudah tumbuh pada bahan-bahan organik atau produk hasil pertanian. Litter dan pakan yang digunakan dalam memelihara unggas bahannya merupakan produk pertanian sehinggaberperan sebagai sumber infeksi Aspergillus atau disebut juga dengan penyakit aspergillosis. Prevalensi kejadian aspergillosis pada peternakan unggas komersial juga pernah dilaporkan cukup tinggi (Gholib, 2005).

Aspergillosis merupakan penyakit saluran pernafasan yang disebabkan oleh infeksi jamur dari genus Aspergillus. Penyakit ini sering menyerang ayam, kalkun, burung liar dan burung dalam sangkar. Aspergillosis di Indonesia di sebabkan oleh beberapa spesies Aspergillus yaitu Aspergillus fumigarus, Aspergillus flavus, Aspergillus glaucus, Aspergillus niger, Aspergillus vesicolor. Jamur- 
jamur ini selalu ditemukan pada pakan dan juga pada bahan-bahan lainnya (Fadilah, 2011). Penyakit Aspergillosis pada unggas merupakan penyakit mikosis terpenting di Indonesia. yang disebabkan oleh Aspergillus fumigatus sebagai penyebab utama, Aspergillus flavus dan Aspergillus niger. Aspergillus bersifat kosmopolitan, sporanya yang mempunyai ukuran sangat kecil dan ringan mudah menyebar di udara sehingga mempunyai peran yang sangat besar dalam mencemari bahan-bahan lain (Alvarez et al., 2010).

Aspergillus merupakan jamur yang mampu hidup pada media dengan derajat keasaman dan kandungan gula yang tinggi. Jamur ini dapat menyebabkan pembusukan pada buah-buahan atau sayuran. Aspergillus ada yang bersifat parasit, ada pula yang besifat saprofit. Aspergillus yang bersifat parasit menyebabkan penyakit aspergillosis pada unggas karena dapat memproduksi suatu zat racun yang disebut dengan aflatoksin. Aspergillus Spp sering ditemukan pada bahan pakan yang disimpan di dalam gudang dengan kelembaban tinggi. Aspergillus Spp dianggap patogen karena dapat menyebabkan suatu penyakit saluran pernafasan, radang granulomatosis pada selaput lendir, mata, telinga, kulit, meningen, bronchus dan paru-paru (Handajani dan Purwoko, 2008).

Ayam kampung merupakan salah satu sumber kekayaan genetik ternak lokal Indonesia. Dibandingkan dengan unggas lain, ayam kampung termasuk salah satu ternak yang memiliki kelebihan, pemeliharaan ayam kampung mudah dan sederhana, biaya yang dikeluarkan relatif murah dan mempunyai daya tahan tubuh yang tinggi terhadap penyakit. Ayam kampung mempunyai peran yang sangat besar bagi kehidupan masyarakat, karena dapat dimanfaatkan sebagai sumber daging dan telur serta sebagai tambahan pendapatan (Solihati dkk., 2006). Penelitian ini bertujuan untuk isolasi dan identifikasi Aspergillus Spp pada paru-paru ayam kampung yang dijual di Pasar Banyuwangi, mengingat banyaknya permintaan masyarakat sekitar terhadap konsumsi daging ayam kampung maka penelitian ini penting untuk dilakukan.

\section{METODE PENELITIAN}

Penelitian ini adalah penelitian deskriptif dengan menggunakan metode Thompson (1996). Aspergillus $\mathrm{Sp}$ diisolasi dengan cara membiakkan paru-paru ayam kampung ke dalam medium Sabouraud Dextrose Agar (SDA) dan diinkubasikan pada suhu kamar selama 1-2 minggu. Selanjutnya biakan diamati setiap hari untuk mengamati pertumbuhan koloni jamur sacara makroskopis dan dibuat slide kultur untuk mengidentifikasi jamur secara mikroskopis. Sampel yang digunakan adalah organ paru-paru dari 20 ekor ayam kampung yang dijual di Pasar Banyuwangi, Jawa Timur dan diambil secara acak. Paru-paru ayam tersebut diambil secara aseptik dari pedagang pasar dan ditempatkan dalam wadah plastik steril, kemudian dibawa ke Laboratorium Instrument Prodi Kedokteran Hewan Universitas Airlangga PSDKU Banyuwangi.

Sampel dimasukkan ke dalam cawan Petri steril secara aseptik, dengan menggunakan gunting paru-paru dipotong dengan ukuran 1-2 $\mathrm{cm}$, potongan paru-paru tersebut dicuci sebanyak $3 \mathrm{x}$ dengan aquades steril yang berisi antibiotik ampicillin $(0.1 \mathrm{cc} / 100 \mathrm{ml})$, kemudian tiap potongan organ ditanamkan pada permukaan media Sabouraud Dextrose Agar (SDA) dan diinkubasikan pada suhu kamar selama 3-7 hari. Pada hari ke-3 dan seterusnya biakan diamati terhadap pertumbuhan koloni jamur secara makroskopik yaitu dengan melihat bentuk, warna, permukaan bawah dan tepi koloni. Apabila ada pertumbuhan koloni yang diduga Aspergillus Spp dilakukan pemeriksaan secara mikroskopis dengan membuat slide preparat pada object glass (Xavier et al., 2007).

Identifikasi jamur yang diduga Aspergillus Spp dilakukan dengan cara penanaman pada slide kultur. Slide kultur dibuat dengan cara metakkan pipet steril pada dasar cawan Petri, kemudian ditempatkan kapas yang telah dibasahi dengan aquades steril pada cawan Petri tersebut, sehingga suasana di dalam cawan Petri menjadi lembab. Selanjutnya diletakkan objek glass di atas pipet, Sabouraud Dextrose Agar (SDA) dipotong dengan ukuran $1 \mathrm{x} 1 \mathrm{~cm}$ dan diletakkan 
di atas objek glass. Kemudian dioleskan potongan SDA dengan biakan jamur pada empat sisi dengan menggunakan ose steril. Potongan agar ditutup dengan cover glass. Kemudian cawan Petri ditutup kembali. Biakan diinkubasikan pada suhu kamar selama 3-7 hari. Pertumbuhan koloni diamati secara mikroskopis terhadap pertumbuhan hifa bersepta, konidia, konidiospor dan phialid dari jamur. Selanjutnya koloni diwarnai dengan meneteskan Lactophenol cotton blue (LCB) pada pinggiran cover glass dan diidentifikasi di bawah mikroskop pada pembesaran 400x (Kunkle et al., 2003).

\section{HASIL DAN PEMBAHASAN}

Hasil isolasi Aspergillus Spp terhadap 20 sampel organ paru-paru ayam kampung dapat dilihat pada tabel 1 .

Hasil positif selanjutnya diamati morfologi koloni untuk masing-masing spesies Aspergillus yang selanjutnya dapat dilihat pada tabel 2 .

Hasil pengamatan terdapat tiga spesies Aspergillus yang ditemukan yaitu Aspergillus flavus, Aspergillus niger dan Aspergillus fumigatus. Aspergillus flavus berwarna hijau kekuningan dengan pinggiran berwarna putih.

Tabel 1. Hasil isolasi Aspergillus Spp pada 20 sampel organ paru-paru ayam kampung

\begin{tabular}{|c|c|c|c|}
\hline No. & Sampel & $\begin{array}{c}\text { Pertumbuhan Pada } \\
\text { Media SDA }\end{array}$ & Jenis Jamur \\
\hline & Paru-paru ayam I & + & Aspergillus Spp \\
\hline 2. & Paru-paru ayam II & + & Aspergillus Spp \\
\hline 3. & Paru-paru ayam III & - & - \\
\hline & Paru-paru ayam IV & - & - \\
\hline 5. & Paru-paru ayam V & - & - \\
\hline 6. & Paru-paru ayam VI & + & Aspergillus Spp \\
\hline 7. & Paru-paru ayam VII & + & Aspergillus Spp \\
\hline & Paru-paru ayam VIII & + & Aspergillus Spp \\
\hline 9. & Paru-paru ayam IX & - & - \\
\hline & Paru-paru ayam X & - & - \\
\hline 11. & Paru-paru ayam XI & - & - \\
\hline 12. & Paru-paru ayam XII & - & - \\
\hline 13. & Paru-paru ayam XIII & + & Aspergillus Spp \\
\hline 14. & Paru-paru ayam XIV & + & Aspergillus Spp \\
\hline 15. & Paru-paru ayam XV & + & Aspergillus Spp \\
\hline 16. & Paru-paru ayam XVI & + & Aspergillus Spp \\
\hline 17. & Paru-paru ayam XVII & - & - \\
\hline 18. & Paru-paru ayam XVIII & - & - \\
\hline 19. & Paru-paru ayam XIX & - & - \\
\hline 20. & Paru-paru ayam XX & - & - \\
\hline & Jumlah Sampel & \multicolumn{2}{|c|}{20} \\
\hline & Persentase Positif & \multicolumn{2}{|c|}{$9(45 \%)$} \\
\hline
\end{tabular}

(-) tidak ada pertumbuhan Aspergillus Spp; (+) jamur Aspergillus Spp

Tabel 2. Morfologi koloni jamur pada media Sabouraud's Dextrose Agar (SDA)

\begin{tabular}{cccc}
\hline Warna Koloni & Tepi Koloni & Permukaan Koloni & Spesies \\
\hline Hijau tua & Putih & Kuning kecoklatan & Aspergillus fumigatus \\
Hitam & Putih & Kuning kecoklatan & Aspergillus niger \\
Hijau kekuningan & Putih & Kuning kecoklatan & Aspergillus flavus \\
\hline
\end{tabular}



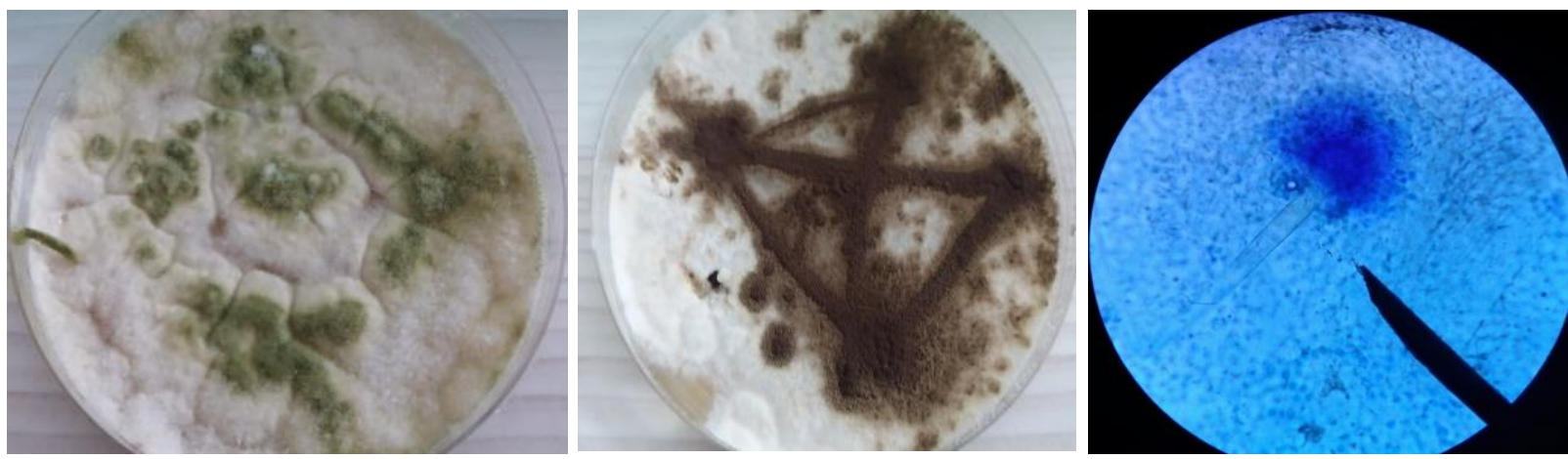

Gambar 1. Koloni makroskopis dan mikroskopis Aspergillus Spp yang tumbuh pada media Sabouraud's Dextrose Agar (SDA)

Aspergillus niger terlihat berwarna hitam dengan pinggiran putih. Aspergillus fumigatus berwarna hijau tua dengan pinggiran putih. Koloni tersebut berwarna terang dengan miselium seperti kapas. Awal mula pengamatan, koloni muncul sebagai filamen putih dan berubah warna tergantung spesiesnya. Koloni Aspergillus juga ditandai dengan konidia yang menyebar. Terdapat tiga spesies Aspergillus yang ditemukan, yaitu Aspergillus niger yang ditunjukkan dengan warna miselium yang berwarna hitam, Aspergillus flavus yang ditunjukkan dengan miselium warna hijau kekuningan, dan Aspergillus fumigatus yang ditunjukkan dengan miselium berwarna hijau tua (Hartana, 2014). Pertumbuhan dan perubahan warna koloni makroskopis dan identifikasi mikroskopis dari Aspergillus flavus, Aspergillus fumigatus dan Aspergillus niger dapat dilihat pada Gambar 1.

Aspergillus secara mikroskopis menunjukkan adanya tangkai konidia (konidiofora), vesikel dan spora/konidia berbentuk bulat berwarna hijau kebiruan. Pemeriksaan mikroskopis menunjukkan adanya tangkai konidia (konidiofora) pendek halus berwarna kehijauan, kepala konidia (vesikel) berbentuk seperti gada (clavate) dan bulat, dan menjadi lonjong (columnar) dengan bertambahnya umur koloni. Sterigmata tampak menutupi setengah bagian atas dari vesikel. Spora/konidia berbentuk bulat, berwarna kehijauan, dan permukaan bergerigi (echinulate) (Redig, 2005). Aspergillus fumigatus koloni muncul sebagai filamen putih kemudian berubah warna hijau tua atau hijau gelap dengan pinggiran putih dan permukan bawah koloni berwarna kekuningan sampai coklat. Koloni Aspergillus fumigatus yang tumbuh berwarna hijau kebiruan, diameter 1-2 $\mathrm{cm}$, permukaan koloni seperti beludru (velvety) (Akan et al., 2002).

Aspergillus niger berwarna koloni hitam dengan pinggiran putih dan permukaan bawah koloni berwarna kekuningan sampai coklat. Secara mikroskopis dicirikan dengan warna konidia, phialid memenuhi seluruh permukaan vesikel dan vesikel bulat besar. Aspergillus niger memiliki warna koloni hitam dan bagian bawah koloni berwarna putih kekuningan. Secara mikroskopis vesikel berbentuk bulat hingga semi bulat. Konidia bulat hingga semi bulat dan berwarna coklat (Wangge dkk., 2012).

Aspergillus flavus yang tumbuh mula-mula berwarna putih kemudian pada hari ke empat berubah menjadi hijau kekuningan dengan pinggiran putih dan permukaan bawah koloni berwarni kekuningan sampai coklat. Aspergillus flavus secara makroskopis koloni yang terlihat berwarna hijau kekuningan dan pada bagian bawahnya berwarna kekuningan sampai coklat. Secara mikroskopis konidiofor tampak jelas, tidak berpigmen, kasar, panjangnya kurang dari $1 \mathrm{~mm}$ (Gautam dan Bhadauria, 2012).

Identifikasi spesies pada masing-masing biakan berdasarkan pemeriksaan mikroskopis dengan melihat morfologi phialidnya, yaitu yang mempunyai tipe dimorfik phialid atau monomorfik atau keduanya. Pembiakan dilakukan pada suhu $37^{\circ} \mathrm{C}$, karena suhu inkubasi 
tersebut merupakan suhu yang sesuai dengan suhu tubuh sehingga kapang Aspergillus yang tumbuh merupakan kapang yang bersifat patogen. Pada suhu inkubasi yang sesuai dengan suhu tubuh $\left(37^{\circ} \mathrm{C}\right)$, cendawan yang patogenik, baik kapang maupun khamir, akan tumbuh lebih subur dibandingkan pada suhu ruangan $\left(25^{\circ} \mathrm{C}\right)$ dan pada suhu ruangan hanya cendawan yang bersifat saprofit yang tumbuhnya subur (Singh $e t$ al., 2009).

Infeksi Aspergillus Spp pada paru-paru ayam kampung disebabkan oleh pakan yang terkontaminasi yang mengandung spora dan berhubungan dengan aspek lingkungan hidup ayam kampung. Spora Aspergillus yang mempunyai ukuran sangat kecil dan ringan mudah menyebar di udara sehingga mempunyai peran yang sangat besar dalam mencemari pakan ternak. Spora Aspergillus Spp dapat masuk ke dalam tubuh unggas secara perinhalasi, spora masuk ke dalam tubuh selanjutnya terbawa aliran darah sehingga menyebabkan kerusakan pada berbagai organ terutama paru-paru (Tyasningsih, 2010).

Faktor-faktor pendukung timbulnya infeksi jamur Aspergillus terutama berhubungan dengan aspek lingkungan dan manajemen kandang dengan ventilasi kurang memadai, berdebu, kelembapan dan temperatur yang sesuai untuk pertumbuhan jamur, litter basah dan lembab, pakan lembab dan berjamur (Alvarez et al., 2012). Menururt Gandjar dkk (2006) bahan pangan yang mudah terkontaminasi jamur Aspergillus $S p$ misalnya pada jenis serelia (jagung, sorgum, beras, gamdum) dan kacangkacangan. Komoditi yang memiliki resiko tinggi terkontaminasi jamur adalah jagung dan kacang tanah karena sumber karbohidrat pada serelia biji-bijian sangat mudah dicemari oleh berbagai jenis jamur. Menurut Fadilah dan Fatkhuroji (2013) Pencegahan infeksi Aspergillus dilakukan dengan cara menjaga kebersihan dilingkungan atau kandang pemeliharaan, pakan dan peralatan kandang yang terkontaminasi jamur harus dibuang, pakan yang diberikan harus bebas dari jamur, peralatan produksi seperti tempat pakan dan minum harus dibersihkan dan didesinfeksi. Sebaiknya, sekam yang digunakan dalam kondisi kering, bersih, dan segar. Tingkatkan sirkulasi udara di dalam kandang dan kontrol kelembaban untuk menghambat pertumbuhan dan penyebaran spora di udara.

\section{KESIMPULAN}

Berdasarkan hasil penelitian dapat disimpulkan bahwa dari 20 sampel paru-paru ayam kampung yang diperiksa sebanyak 9 sampel (45\%) dapat diisolasi dan diidentifikasi Aspergillus Spp dan 11 sampel (55\%) tidak ditemukan adanya pertumbuhan Aspergillus Spp.

\section{UCAPAN TERIMA KASIH}

Peneliti mengucapkan terima kasih kepada Rektor Universitas Airlangga, Dekan Fakultas Kedokteran Hewan dan Ketua Program Studi Kedokteran Hewan Universitas Airlangga PSDKU Banyuwangi atas diberikannya kesempatan untuk melaksanakan penelitian ini sehingga dapat terselesaikan dengan baik.

\section{DAFTAR PUSTAKA}

Akan, M., R. Hazro`glu, Z. Ilhan, B. Sareyy"upo glu, R. Tunca. 2002. A case of aspergillosis in a broiler breeder flock. Avian Diseases 46(2): 497-501.

Alvarez-Perez, S., A. Mateos, L. Dominguez, E. Martinez-Nevado, J.L. Blanco, M.E. Garcia. 2010. Polyclonal Aspergillus fumigatus infection in captive penguins. Veterinary Microbiology 144(3): 444-449.

Fadilah, R., A. Polana. 2011. Mengatasi 71 Penyakit Pada Ayam. Agromedia Pustaka, Jakarta.

Fadilah, R., Fatkhuroji. 2013. Memaksimalkan Produksi Ayam Ras Petelur. Agromedia Pustaka, Jakarta.

Gandjar, Indrawati, O. Sjamsuridzal, Wellyzar, Ariyanti. 2006. Mikologi Dasar dan Terapan. Gramedia Pustaka, Jakarta. 
Gautam, A.K., R. Bhadauria. 2012. Characterization of Aspergillus species associated with commercially stored triphala powder. African Journal Biotechnol 11 (104): 16814-16823.

Gholib, D. 2005. Pengembangan teknik serologi untuk pemeriksaan aspergillosis ayam. Jurnal Ilmu Ternak dan Veteriner 10(2). 143-149.

Handajani, N.S., T. Purwoko. 2008. Aktivitas ekstrak rimpang lengkuas (Alpinia galaga) terhadap pertumbuhan jamur Aspergillus sp. penghasil aflatoksin dan Fusarium moniliforme. Biodiversitas 9(5): 161-164.

Hartana, S.N. 2014. Keanekaragaman Cendawan yang Diisolasi di Lokasi Perkandangan Ayam. Skripsi. Departemen Ilmu Penyakit Hewan dan Kesehatan Masyarakat Veteriner. Fakultas Kedokteran Hewan, Institut Pertanian Bogor.

Kunkle, R.A., Y.M. Saif, H.J. Barnes, J.R. Glisson. 2003. Aspergillosis, Diseases of Poultry. Iowa State University Press, Ames (11): 883-895.

Redig, P. 2005. Mycotic infections in birds I: Aspergillosis. North American Veterinary Conference Proceedings, Eastern States Veterinary Association 1192-1194.
Singh, S., M.K. Borah, D.K. Sharma. 2009. Aspergillosis in turkey poults. Indian Journal of Veterinary Pathology 33(2): 220221.

Solihati, N., R. Idi, R. Setiawan, I.Y. Asmara, B.I. Sujana. 2006. Pengaruh lama penyimpanan semen cair ayam buras pada suhu $5^{\circ} \mathrm{C}$ terhadap periode fertil dan fertilisasi sperma. Jurnal Ilmu Ternak 6(1): 7-11.

Thompson, J.C. 1996. Techniques for the Isolation of the common pathogenic fungi, dilution plating and the ringworm fungi. Medium 2:110-120.

Tyasningsih, W. 2010. Potensi pakan sebagai sumber pencemaran Aspergillus Spp penyebab Aspergillosis pada unggas. Vetenaria medika 3(1): 31-34.

Wangge, E.S.A., D.N. Suprapta, G.N.A. Wirya. 2012. Isolasi dan identifikasi jamur penghasil mikotoksin pada biji kakao kering yang dihasilkan di Flores. J. Agric. Sci. and Biotechnol 1(1): 39-47.

Xavier, M.O., M.P. Soares, A.R.M. Meinerz. 2007. Aspergillosis, a limiting factor during recovery of captive magellanic penguins. Brazilian Journal of Microbiology 38(3): 480-484. 